\title{
A new genus and species of gall midge (Diptera, Cecidomyiidae) associated with Microgramma vacciniifolia (Langsd. \& Fisch.) Copel. (Polypodiaceae) from Brazil
}

\author{
Valéria Cid Maia ${ }^{1} \&$ Marcelo Guerra Santos ${ }^{2}$
}

\begin{abstract}
'Departamento de Entomologia, Museu Nacional, Quinta da Boa Vista, São Cristóvão, 20940-040 Rio de Janeiro-RJ, Brazil. maiavcid@acd.ufrj.br ${ }^{2}$ Departamento de Ciências, Universidade do Estado do Rio de Janeiro, Rua Dr. Francisco Portela 1470, 24435-005 São Gonçalo-RJ, Brazil. marceloguerrasantos@gmail.com
\end{abstract}

\begin{abstract}
A new genus and species of gall midge (Diptera, Cecidomyiidae) associated with Microgramma vacciniifolia (Langsd. \& Fisch.) Copel. (Polypodiaceae) from Brazil. A new gall midge genus Primadiplosis Maia, gen. nov. and a new species, $P$. microgrammae Maia, sp. nov., that induces galls on stems of the fern Microgramma vacciniifolia (Langsd. \& Fisch.) Copel. are described from Brazil (larva, pupa, male, female, and gall).
\end{abstract}

KEYWORDS. Cecidomyiidi; gall; Primadiplosis microgrammae; restinga; taxonomy.

RESUMO. Novo gênero e espécie de Cecidomyiidae (Diptera) associados a Microgramma vacciniifolia (Langsd. \& Fisch.) Copel. (Polypodiaceae) do Brasil. Um novo gênero de Cecidomyiidae, Primadiplosis Maia, gen.nov., e uma nova espécie, P. microgrammae Maia, sp. nov., que induz galhas no caule da samambaia Microgramma vacciniifolia (Langsd. \& Fisch.) Copel. (Polypodiaceae) são descritos do Brasil (larva, pupa, macho, fêmea e galha).

PALAVRAS-CHAVE. Cecidomyiidi; galha; Primadiplosis microgrammae; restinga; taxonomia.

Galls on ferns are poorly known in Brazil, where nine morphotypes are recorded on eight plant species, six genera and four families. They are induced by Eriophyidae, Diptera, Lepidoptera, Thysanoptera and Hemiptera (Table I). In this paper, the first record of a gall midge (Cecidomyiidae, Diptera) on ferns in Brazil is presented. The new species induces ovoid stem galls on Microgramma vacciniifolia (Langsd. \& Fisch.) Copel. (Polypodiaceae), a Neotropical epiphyte and sometimes rupicolous fern that is widely distributed in the sandy coastal plains (restingas) of Rio de Janeiro State. The gall midge belongs to a new genus and species that is described here.

\section{MATERIAL AND METHODS}

Field work was carried out from June, 2008 to August, 2009 in the restinga of the Environmental Protection Area of Maricá (2257'50"S e 4250'44”'W), Maricá, Rio de Janeiro State, Brazil. Ovoid galls on Microgramma vacciniifolia were collected and transported to the laboratory. Part of the sample was packed in transparent plastic bags with moist cotton and checked daily for adult emergence. The remaining galls were dissected under a stereoscopic microscope to obtain larvae and pupae. All specimens were first preserved in 70\% alcohol and later mounted on slides following the methodology of Gagné (1994). The studied material (including the types) are incorporated in the Diptera collection of Museu Nacional (MNRJ), Rio de Janeiro, Brazil. Terminology of the adults follows McAlpine (1981) and that of the immature stages follows Gagné (1989). The description of the new taxa was done by V. C. Maia, and the field and laboratory work were done by M. G. Santos.

\section{RESULTS}

The gall midge that induces ovoid galls on Microgramma vacciniifolia belongs to the supertribe Cecidomyiidi based on the number $(n=12)$ and shape of the male flagellomeres (binodal), but it does not fit in any known tribe.

\section{Primadiplosis Maia, gen. nov.}

Diagnosis. Palpus three-segmented; male flagellomeres with two nodes and three separate circumfila, circumfilar loops irregular in length. Wing with R5 joining $\mathrm{C}$ beyond wing apex; tarsal claws one-toothed and bowed near basal third; empodia barely reaching beyond bend in tarsal claws. Male terminalia: gonocoxite with mesobasal lobes, gonostylus cylindrical, slightly tapered from base to apex, hypoproct concave apically, conspicuously longer and thinner than cerci. Ovipositor barely protrusible; cerci separate. Larval spatula absent.

Adult. Head: occipital process absent; palpus three-segmented; male flagellomeres binodal and tricircumfilar. Wing: R5 curved, joining C beyond wing apex; Rs absent or barely evident, present only at its junction with R5 and situated be- 
Table I. Data on galls on ferns in Brazil.

\begin{tabular}{|c|c|c|c|c|}
\hline Plant family & Host plant species & $\begin{array}{l}\text { Number of } \\
\text { morphotypes }\end{array}$ & Galler & Reference \\
\hline Blechnaceae & $\begin{array}{l}\text { Blechnum volubile Kaulf. [= Salpichaena } \\
\text { volubilis (Kaulf.) J.Sm.]. }\end{array}$ & 1 & Eriophyidae & Houard (1933) \\
\hline Cyatheaceae & Cyathea sp. & 1 & Not determined & Maia et al. (2008) \\
\hline \multirow[t]{2}{*}{ Hymenophyllaceae } & Hymenophyllum ciliatum (Sw.) Sw. & 1 & Diptera & Houard (1933) \\
\hline & Hymenophyllum lineare (Sw.) Sw & 2 & Diptera & Houard (1933) \\
\hline \multirow[t]{4}{*}{ Polypodiaceae } & $\begin{array}{l}\text { Microgramma squamulosa (Kaulf.) de la } \\
\text { Sota }\end{array}$ & 1 & $\begin{array}{l}\text { Tortrimosaica polypodivora Brown \& } \\
\text { Baixeras (2004) (Tortricidae, Lepidoptera) }\end{array}$ & $\begin{array}{l}\text { Kraus et al. (1993); Brown } \\
\text { et al. (2004) }\end{array}$ \\
\hline & $\begin{array}{l}\text { Polypodium crassifolium L. [= Niphidium } \\
\text { crassifolium } \text { (L.) Lellinger] }\end{array}$ & 1 & Coccidae (Hemiptera) & Houard (1933) \\
\hline & Polypodium sp. (Serpocaulon sp.) & 1 & Thripsidae (Thysanoptera) & Houard (1933) \\
\hline & $\begin{array}{l}\text { Pteridium aquilinum Kunh. }[=P . \\
\text { arachonoideum (Kaulf.) Maxon] }\end{array}$ & 1 & $\begin{array}{l}\text { Phaonia gallicola Albuquerque (1958) } \\
\text { (Diptera, Muscidae) }\end{array}$ & Martins \& Pimenta (1988) \\
\hline
\end{tabular}

fore midlength of R1; base of M slightly curved; M3 present; $\mathrm{CuA}$ forked; CuP present. Legs: first tarsomeres without spur; tarsal claws one-toothed on all legs and bowed near basal third; empodia well developed, reaching beyond bend in tarsal claws. Male terminalia: gonocoxite stout with mesobasal lobes; gonostylus cylindrical; cerci wide; hypoproct concave apically, longer and thinner than cerci; aedeagus elongate, surpassing hypoproct, with many socketlike sensoria; gonostylus cylindrical, slightly tapered from base to apex, setulose at basal third, ridged elsewhere. Ovipositor barely protrusible; cerci separate.

Pupa. Head: antennal bases rounded apically; a single pair of lower facial setae present; lateral facial papillae absent; vertexal setae very short; prothoracic spiracle only three times as long as broad; abdominal tergites 2-8 uniformly spiculose.

Larva. Body cylindrical; spatula absent; full complement of lateral papillae, terminal segment with four pairs of setose papillae, two shorter than the others.

Type species. Primadiplosis microgrammae Maia, sp. nov.

Etymology. The generic name is composed by prima (a Latin word that means "first") + diplosis (a suffix commonly used for Cecidomyiidi that means "double") and refers to the first record of a gall midge on fern in Brazil.

Remarks. Primadiplosis reaches couplet 38 of Gagné 1994, if one ignores the number of segments of palpi. As the new genus has a single tooth on all legs, it does not fit in any option.

Cecidomyiidi include 36 Neotropical unplaced genera (Gagné 2004). Among them, Primadiplosis appears to be more similar to Clusiamyia Maia, 1996, based mainly on characters of the male terminalia, specially the proportions among cerci, hypoproct, and aedeagus and the shape of cerci and hypoproct. The genus differs in the shape and chaetotaxy of female cerci (not completely divided and with a ventroapical pair of modified setae in Clusiamyia; completely separate and with a ventroapical pair of modified setae in Primadiplosis), shape of female hypoproct (triangular in Clusiamyia and straight at distal margin in Primadiplosis), shape of tarsal claws (bowed beyond midlength and bowed near middle in Clusiamyia; bent near basal third and not bowed in Primdiplosis), number of segments of the palpi (one in Clusiamyia and three in Primadiplosis), shape of female circumfila (sinuous in Clusiamyia and straight in Primadiplosis), length of circumfilar loops of male (regular in Clusiamyia and irregular in Primadiplosis), shape of pupal antennal bases (produced in Clusiamyia and not produced in Primadiplosis), superior frontal horn (present in Clusiamyia and absent in Primadiplosis), length of pupal prothoracic spiracle (not prominent, like a spot in Clusiamyia and prominent in Primadiplosis), pupal integument (entirely grainy in Clusiamyia and smooth in Primadiplosis), and degree of sclerotization of pupa (strongly sclerotized in Clusiamyia and barely sclerotized in Primadiplosis).

\section{Primadiplosis microgrammae Maia, sp. nov.}

(Figs. 1-17)

Adult. Length: male: $2.8-4.8 \mathrm{~mm}(\mathrm{n}=5)$; female: 4.0 $4.5 \mathrm{~mm}(\mathrm{n}=2)$. Head (Fig. 1). Eye facets hexagonal, closely approximated. Antennae: scape obconic; pedicel globose; two first flagellomeres connate; male flagellomeres subequal in length, varying from $0.17-0.25 \mathrm{~mm}$, binodal and tricircumfilar, circumfilar loops irregular in length, internodes entirely setulose and necks setulose only basally (Fig. 2); female flagellomeres cylindrical with ring-like circumfila (Fig. 3); $10^{\text {th }}$ to $12^{\text {th }}$ flagellomeres slightly shorter than the preceding ones $\left(10^{\text {th }}\right.$ flagellomere: $0.14-0.15 \mathrm{~mm}$ of length; $11^{\text {th }}$ flagellomere: $0.13-0.14 \mathrm{~mm} ; 12^{\text {th }}$ flagellomere: $0.14 ; 1^{\text {st }}$ to $9^{\text {th }}$ flagellomeres varying from $0.18-0.15 \mathrm{~mm}$ ); necks setulose only basally (Fig. 3); $12^{\text {th }}$ flagellomere with setulose apical process in both sexes (Figs. 4-5). Frontoclypeus with few long setae. Labrum triangular, long-attenuate, with two pairs of ventral sensory setae. Hypopharynx with anteriorly directed lateral setulae. Labella subtriangular, each with lateral setae and two short mesal setae. Palpus: first segment with $0.03-0.04 \mathrm{~mm}$ of length; second segment with $0.03-0.05 \mathrm{~mm}$ of length; third segment with $0.04-0.06 \mathrm{~mm}$ of length. 

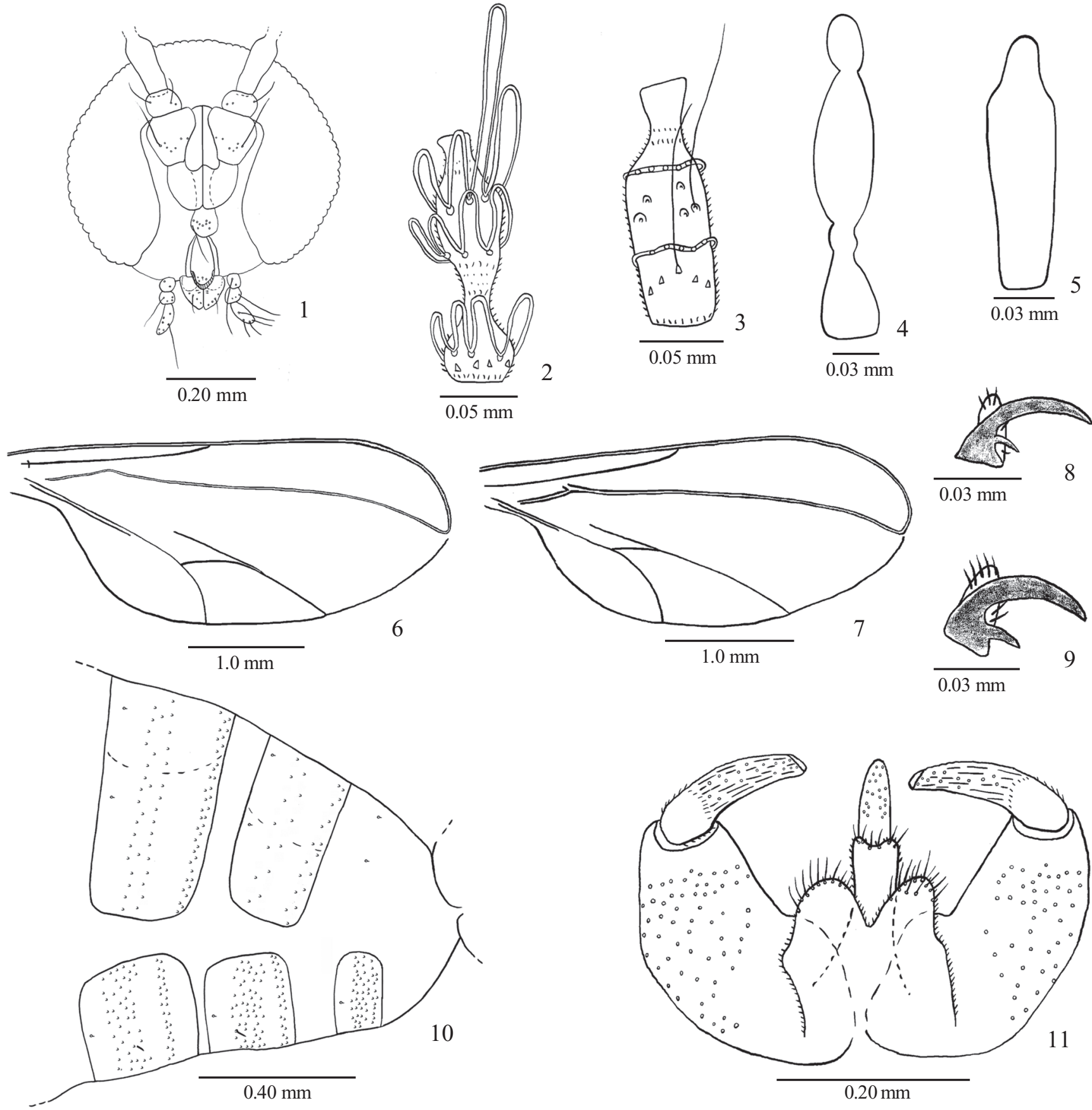

Figs. 1-11. 1, Primadiplosis microgrammae sp. nov., female head, frontal view; 2, male flagellomere 5; 3, female flagellomere 6; 4, male flagellomere 12; 5, female flagellomere $12 ; 6$, male wing; 7 , female wing; 8 , male fore tarsal claw; 9 , female fore tarsal claw; 10, male abdominal segments 6-8, lateral view; 11, male terminalia, dorsal view.

Thorax. Anepisternum with setae. Wing length (from arculus to apex): male, 2.6-3.7 $\mathrm{mm}(\mathrm{n}=6)$; female, 3.3$3.5 \mathrm{~mm}(\mathrm{n}=2)$; Rs absent (Fig. 6) or barely evident, present only at its junction with R5 and situated slightly before midlength of R1 (Fig. 7). Tarsal claws one-toothed and bowed near basal third. Empodium barely reaching beyond bend in tarsal claws (Figs. 8-9).

Abdomen. Male (Fig. 10): tergites 1-6 rectangular with caudal setae along entire posterior margin, many setae at midlength, two anterior trichoid sensilla, and elsewhere with scattered scales; tergite 7 rectangular with rows of posterior and midlength setae, two anterior trichoid sensilla, and elsewhere with scattered scales; tergite 8 not sclerotized with only two anterior trichoid sensilla; sternites 2-7 rectangular, with setae posteriorly and at midlength, two anterior trichoid sensilla, and elsewhere with scattered scales; sternite 8 ovoid with scattered setae and scales o posterior two-thirds, and with anterior pair of trichoid sensilla; terminalia (Fig. 11): 

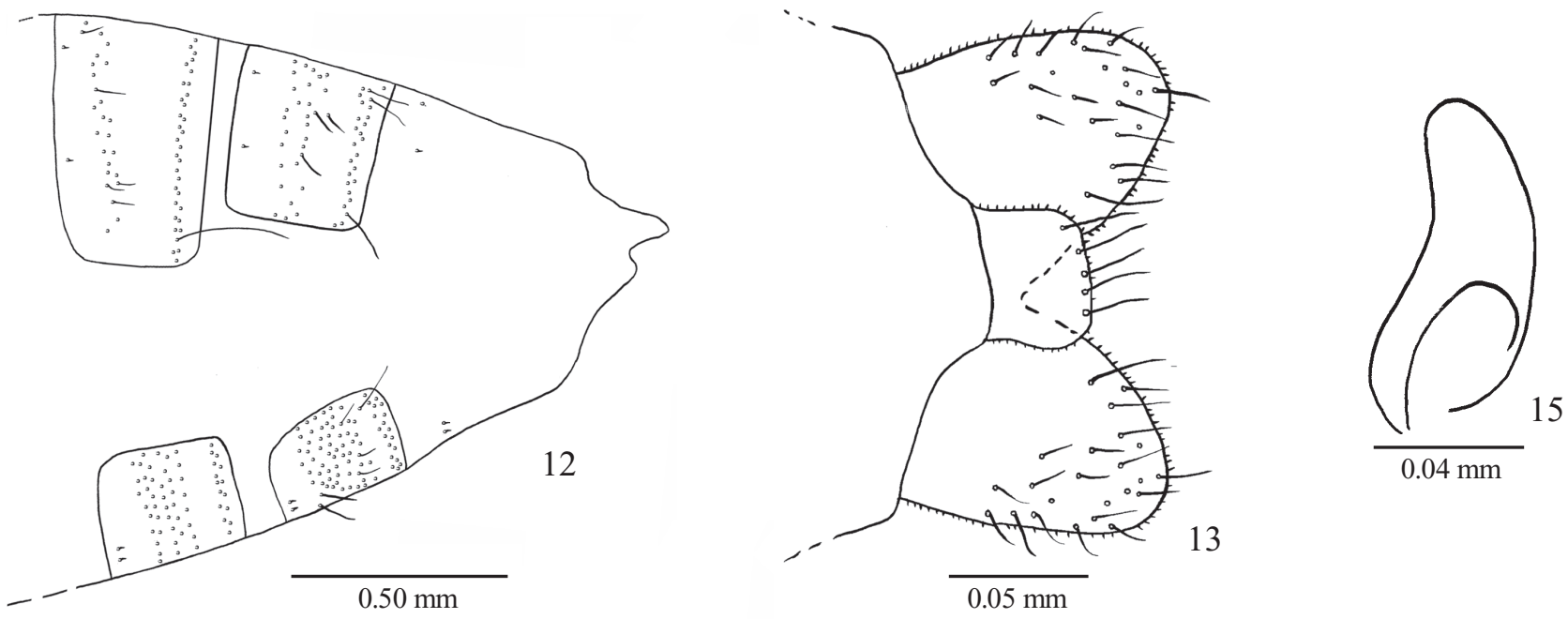

3
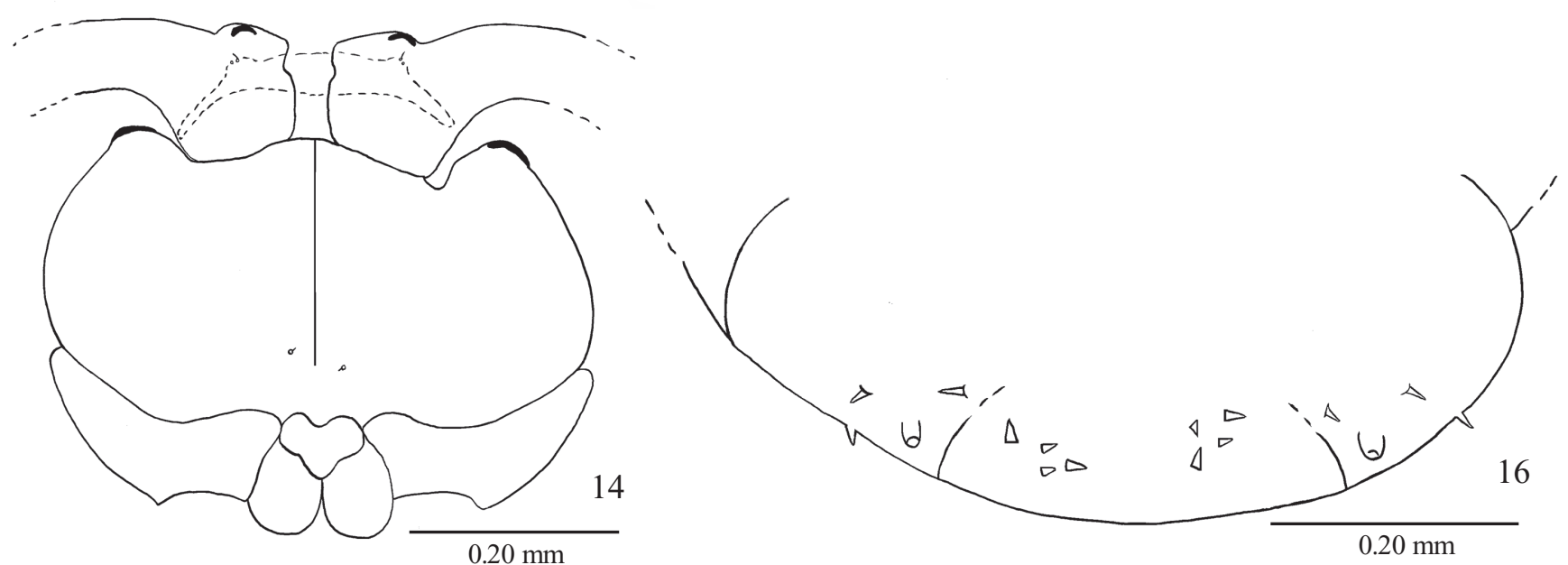

Figs. 12-16. 12, Primadiplosis microgrammae sp. nov., female abdominal segment 6 to end, lateral view; 13, female cerci and hypoproct, ventral view; 14 pupa head, frontal view; 15, pupal prothoracic spiracle; 16, larva terminal segment, dorsal view.

gonocoxite wide, 2.3 times as long as wide; mesobasal lobes moderately developed, gonostylus relatively short, 0.5 as long as gonocoxite, 4.5-4.0 times as long as wide, setulose at basal third and ridged elsewhere; cerci rounded at apex; hypoproct slightly bilobed, conspicuously longer and thinner than cerci; aedeagus much longer than hypoproct, tapering to apex. Female (Fig. 12): tergites 1-7 rectangular with caudal setae along entire posterior margin, many setae at midlength, two anterior trichoid sensilla, and elsewhere with scattered scales; tergite 8 not sclerotized with only two anterior trichoid sensilla; sternites 2-7 rectangular, with setae posteriorly and at midlength, two anterior trichoid sensilla, and elsewhere with scattered scales, sternite 8 not sclerotized with only two anterior trichoid sensilla. Ovipositor short, barely protrusible; cerci separate and setose, all setae similar in length; hypoproct as long as wide, with several posterior setae (Fig. 13).

Pupa. Length: 2.8-4.2 mm ( $\mathrm{n}=6)$. Head (Fig. 14): apical setae almost inconspicuous with $0.01 \mathrm{~mm}$ of length $(\mathrm{n}=4)$; antennal bases rounded apically; lower facial papillae with seta very short $(0.005 \mathrm{~mm}$ of length, $\mathrm{n}=3)$. Thorax: prothoracic spiracle digitiform (length: $0.10-0.14 \mathrm{~mm}, \mathrm{n}=5$ ) (Fig. 15). Abdomen: tergites $2-8$ uniformly spiculose.

Larva. Length: $3.2-3.3 \mathrm{~mm}(\mathrm{n}=2)$; full complement of lateral papillae; terminal segment with four pairs of setose papillae, two shorter than the others (Fig. 16).

Gall (Fig. 17). 4.4-8.8 mm long and 4.1-5.9 mm broad $(n=6)$; ovoid; green; one-chambered; covered by scattered scales that become imbricate at the apices of the gall, lanceolate, filiform tip, peltately attached, white with a castaneous central point. Number of larva/gall: 01 .

Biology. Pupation in the gall.

Type material. Holotype male, BRAZIL, Rio de Janeiro State, Maricá, APA Maricá, VI/2008, M. Guerra Santos col., MNRJ.

Paratypes: same data as holotype, 1 male and 1 pupal exuvia; same locality and collector, 16.VII.2008, 1male, 1 


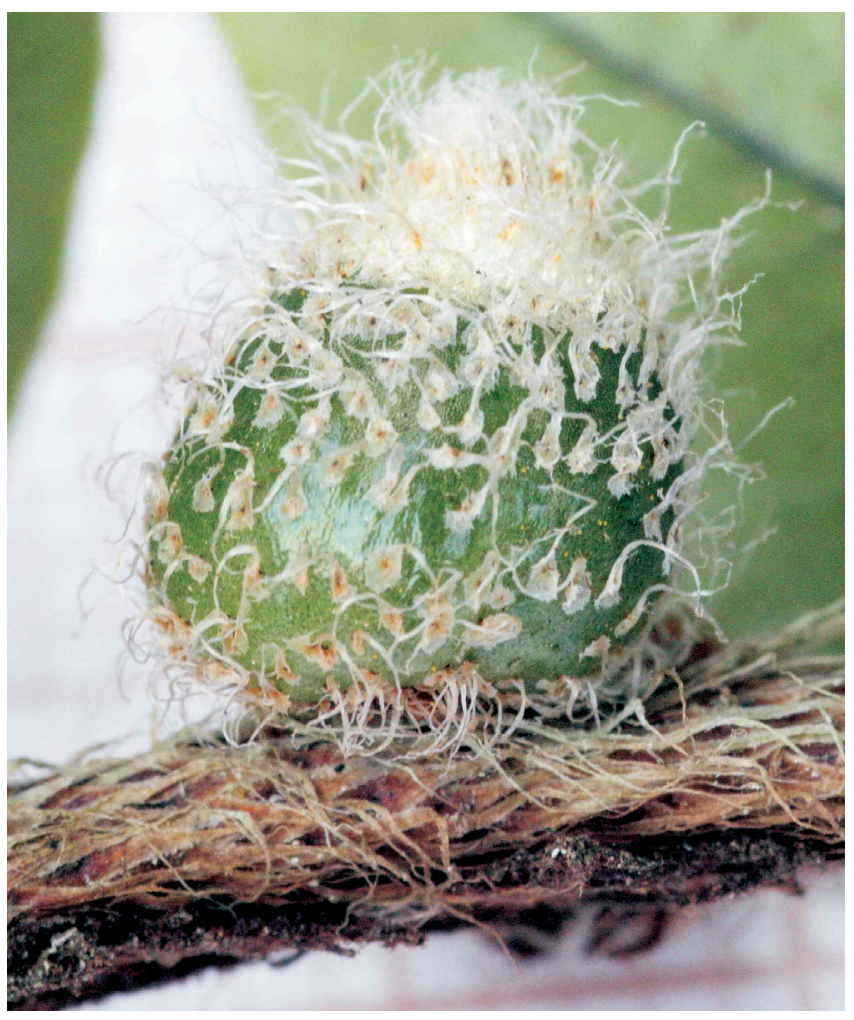

Fig. 17. Gall of Primadiplosis microgrammae on Microgramma vacciniifolia (Langsd. \& Fisch.) Copel. (Polypodiaceae), general aspect.

female and 2 pupal exuviae; 15.VIII.2008, 1 male; 17.VIII. 2008, 1 male and 1 pupal exuvia; VIII.2009, 2 larvae; I.2009, 1 male, 1 female and 2 pupal exuviae; MNRJ.

Etymology. The name microgrammae is the genitive of the host plant genus.

\section{ACKNOWLEDGEMENTS}

We thank CNPq (Conselho Nacional de Desenvolvimento Científico e Tecnológico, Proc. 472084/2007-0, and 301197/ 2007-5), FAPERJ (Fundação Carlos Chagas Filho de Amparo à Pesquisa do Estado do Rio de Janeiro, Proc. E-26/170.557/ 2007, and E-26/110.162/2010), and PROCIÊNCIA-UERJ by the financial support, and Dr. Raymond J. Gagné (USMN, USA) for the critical review.

\section{REFERENCES}

Brown J. W.; J. Baixeras; J. A. Solorzano-Filho \& J. E. Kraus. 2004. Description and life history of an unusual fern-feeding tortricid moth (Lepidoptera: Tortricidae) from Brazil. Annals of the Entomological Society of America 97: 865-871.

Gagné, R. J. 1989. The plant-feedings gall midges of North America. Ithaca, Comstock, New York, $x i+356 \mathrm{p}$.

Gagné, R.J. 1994. The gall midges of the Neotropical region. Ithaca, Cornell University Press. 352 p.

Gagné, R. J. 2004. A Catalog of the Cecidomyiidae (Diptera) of the World. Entomological Society of Washington, Washington, 408 p.

Houard, C. 1933. Les Zoocécidies des Plantes de L'Amérique du Sud et de L'Amérique Centrale. Paris, Hermann et Cie., 549 p.

Kraus, J.E.; G. Montenegro \& A. J. Kim. 1993. Morphological studies on entomogenous stem galls of Microgramma squamulosa (Kauf.) Sota (Polypodiaceae). American Fern Journal 83: 120-128.

Maia, V. C.; M. A. G. Magenta \& S. E. Martins. 2008. Ocorrência e caracterização de galhas de insetos em áreas de restinga de Bertioga (São Paulo, Brasil). Biota Neotropica 8: 167-197.

McAlpine, J.F. 1981. Morphology and terminology: adults, p. 9-63. In: J.F. McAlpine; B.V. Peterson; G.E. Shewell; H. J.Teskey; J.R. Vockeroth \& D.M. Wood (Eds). Manual of Nearctic Diptera. vol. 1, Monograph 27, Ottawa, Research Branch, Agriculture Canada, 674 p.

Martins, R. P. \& H. R. Pimenta. 1988. Phaonia gallicola Albuquerque, 1958 (Diptera:Muscidae) a gall maker on Pteridium aquilinum Kunh. (Pteridophyta). Anais da Sociedade Entomológica do Brasil 17: 181-182. 